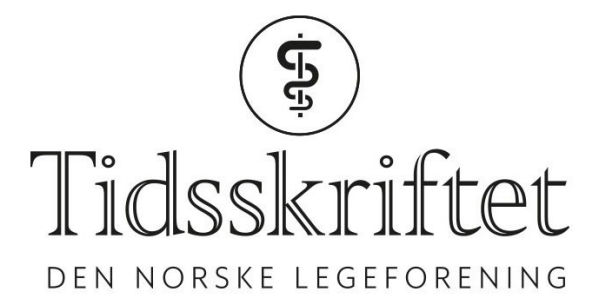

\title{
Det store tarmkreftlotteriet
}

DEBATT

\section{BJØRN HOFMANN}

E-post: bjoern.hofmann@ntnu.no Bjørn Hofmann (f. 1964) er professor i medisinsk filosofi og etikk ved Norges teknisknaturvitenskapelige universitet i Gjøvik og ved Universitetet i Oslo. Han forsker og underviser innenfor medisinsk filosofi, etikk, vitenskapsteori og teknologivurdering.

Forfatter har fylt ut ICMJE-skjemaet og oppgir følgende interessekonflikter: Han har tidligere utredet etiske aspekter ved tarmkreftscreening og har bidratt til Helsedirektoratets rapport om tarmkreftscreening. Innholdet i dette innlegget er helt og holdent forfatterens eget og må ikke tillegges noen av de institusjonene han arbeider for.

Skillet mellom forskning og helsetjeneste er ikke alltid klart, noe som reiser metodiske og etiske spørsmål. Det kommer tydelig frem i forslaget om å innføre tarmkreftscreening som «en kontinuerlig systematisk og randomisert utprøving» i Norge.

Helsetjenesten møter økende krav til å kombinere helsetjenester med kunnskapsproduksjon, for eksempel i tilgang til utprøvende behandling og ved innføring av screening. Ø $\varnothing t$ kunnskap om metodene som brukes er utvilsomt et gode, men om skillet mellom forskning og helsetjeneste viskes ut, møter vi også en rekke metodiske og etiske utfordringer. Jeg skal her peke på fem. La meg bruke innføringen av tarmkreftscreening som eksempel.

I forbindelse med (mulig) innføring av tarmkreftscreening i Norge (1) argumenteres det for at tarmkreftscreening bør innføres som «en kontinuerlig systematisk og randomisert utprøving» (2). Man foreslår å innføre et nasjonalt forskningsprosjekt der det trekkes lodd om hvilken screeningmetode folk skal få (3). Med dette ønsker man både å tilby screening og å forske. Her har man utvilsomt et poeng, da man i andre land har innført screening uten å ha tilstrekkelig kunnskap om effekten (3). Dermed kjenner man ikke utbyttet av screeningen, og risikerer at vi aldri finner det ut.

Samtidig medfører forslaget en overskridelse av det tradisjonelle skillet mellom forskning og helsehjelp, som har fundamentalt forskjellige formål. Forskningens mål er kunnskap, mens helsehjelp skal fremme helse. Forskeren og helsepersonell har også ulike interesser (4). Hva skjer når vi blander disse? Klarer folk å forstå når tiltaket tjener dem og når det det tjener andre? Får vi bedre kunnskap og bedre tjenester? Øker kravene om utprøvende metoder? Vil tilliten til helsetjenesten opprettholdes? Dette er vesentlige spørsmål når man $\emptyset$ nsker å blande forskning og helsetjenester.

\section{Skille forskning og helsetjeneste}

Problemstillingen er selvsagt ikke ny. Allerede i dag forskes det klinisk. Men vi har en rekke tiltak for å klargjøre skillet: Godkjenning av etisk komité, forskerutdanning og ekstra informasjon til pasienter. Likevel er det mange som ikke forstår forskjellen. Den 
«terapeutiske feiloppfatning» er utbredt. Å «ta i bruk systematisk og kontinuerlig utprøving med randomisering», kan forsterke uklarheten om når et tiltak faktisk er til hjelp. Å randomisere pasienter $\mathrm{i}$ «helsetiltak» kan gi inntrykk av at helsetjenesten er et lotteri.

Også i kvalitetssikring og følgeforskning kan skillet mellom forskning og helsetjeneste være uklart. Men det gjelder metode, ikke formål (5). Dessuten er det ikke dette man foreslår, men snarere en kontinuerlig effektforskning der befolkningen randomiseres til ulike tilbud (2). Spørsmålet er om resultatet av en slik blanding av forskning og helsehjelp kan gi både dårligere kunnskap og dårligere helsehjelp. Dessuten reiser det spørsmål om hvilke krav som skal stilles til «kontinuerlig systematisk og randomisert utprøving», slik at friske mennesker beskyttes mot unødig risiko (6). Gjelder Verdens helseorganisasjons kriterier for screening?

Vi skal selvsagt være åpne for nye modeller for forskning, og vi skal forhindre innføring av helsetjenester som ikke er godt nok utprøvd. Spørsmålet er om den foreslåtte modellen er med på å fremme slik innføring mer enn å forhindre den:Vi trenger ikke lenger god og rigid effektforskning før implementering, fordi vi kan teste ut metoder mens vi innfører dem.

Presset for at helsetjenesten skal finansiere utprøvende behandling er allerede stort. Med en mindre klar grense mellom forskning og helsetjeneste, vil dette presset kunne øke på en lang rekke områder. «Vi gjør det jo allerede for tarmkreft», vil man lett kunne hevde.

Mens randomisering av pasienter til undersøkelse og behandling kan være lett å få til ved nødvendige helsetjenester ( og desperate pasienter), vil det være annerledes for preferansesensitive tjenester, som screening. Her vil blandingen av forskning og helsetjeneste lett kunne undergrave tilliten til tjenesten. Hvorfor skal jeg delta i et «tarmkreftlotteri» når det finnes metoder som har dokumentert effekt (sigmoidoskopi)? Bør jeg ikke kunne velge?

Det er ingen tvil om at nasjonale screeningprogrammer er en ypperlig måte å finansiere forskning på (3), men forslaget om å blande forskning og helsetjeneste reiser metodiske og etiske spørsmål $(7,8)$. Det baserer seg på korrekt diagnose: Vi har begrenset kunnskap om metodene for tarmkreftscreening. Men forslaget fortjener kritisk refleksjon. Jeg har her reist fem spørsmål som jeg mener er viktige å besvare. For det første, klarer vi å ri to hester samtidig, eller blir det dårlig forskning og dårlig folkehelse? For det andre, vil folk forstå hva de inviteres til - vil de gi et gyldig samtykke? For det tredje, vil vi få et ytterligere økt press på tilgang til utprøvende behandling? For det fjerde, hvilke krav skal stilles til denne typen «kontinuerlig systematisk og randomisert utprøving» slik at friske mennesker beskyttes mot unødig risiko? For det femte, og kanskje viktigst, vil vi undergrave helsetjenestens viktigste ressurs: tillit? Mens lotterimetaforen er godt begrunnet $\mathrm{i}$ forskning, er den farlig for helsetjenesten.

\section{LITTERATUR:}

1. Helsedirektoratet. Nasjonalt screeningprogram mot tarmkreft - status og anbefalinger. https://helsedirektoratet.no/Documents/Kreft/Rapport\%20om\%2oet\%2oNasjonalt\%2oscreeningprogra m\%2omot\%2otarmkreft\%20300617.pdf(22.8.2017).

2. Kalager M, Stoltenberg C. Screening for den enkelte og kunnskap for alle. Tidsskr Nor Laegeforen 2017; 137: 858. [PubMed]

3. Hoff G. Gastrointestinal cancer screening: screening may release new research funding to improve health service also in routine clinics. Scand J Gastroenterol 2015; 50: 718 - 26. [PubMed]

4. Holm S, Hofmann B. Forsknings- og vitenskapsetikk. Forskning i medisin og biofag. 2. utg. Oslo: Gyldendal Akademisk, 2008: 550.

5. Veileder til lov 20. juni $2008 \mathrm{nr} .44$ om medisinsk og helsefaglig forskning (helseforskningsloven). https://www.regjeringen.no/no/dokumenter/Veileder-til-lov-2o-juni-20o8-nr-44-om-medisinsk-og-hels efaglig-forskning-helseforskningsloven/id599512/ (22.8.2017). 
6. Hoff G. Different standards for healthy screenees than patients in routine clinics? World J Gastroenterol 2013; 19: 8527-30. [PubMed][CrossRef]

7. Hofmann B. Ethical issues with colorectal cancer screening-a systematic review. J Eval Clin Pract 2017; 23: 631 - 41. [PubMed][CrossRef]

8. Hofmann B. Etiske aspekter ved tarmkreftscreening. Rapport. Gjøvik: NTNU, 2016.

Publisert: 18. september 2017. Tidsskr Nor Legeforen. DOI:10.4045/tidsskr.17.0617

Mottatt 21.7.2017, godkjent 22.8.2017.

(C) Tidsskrift for Den norske legeforening 2020. Lastet ned fra tidsskriftet.no 